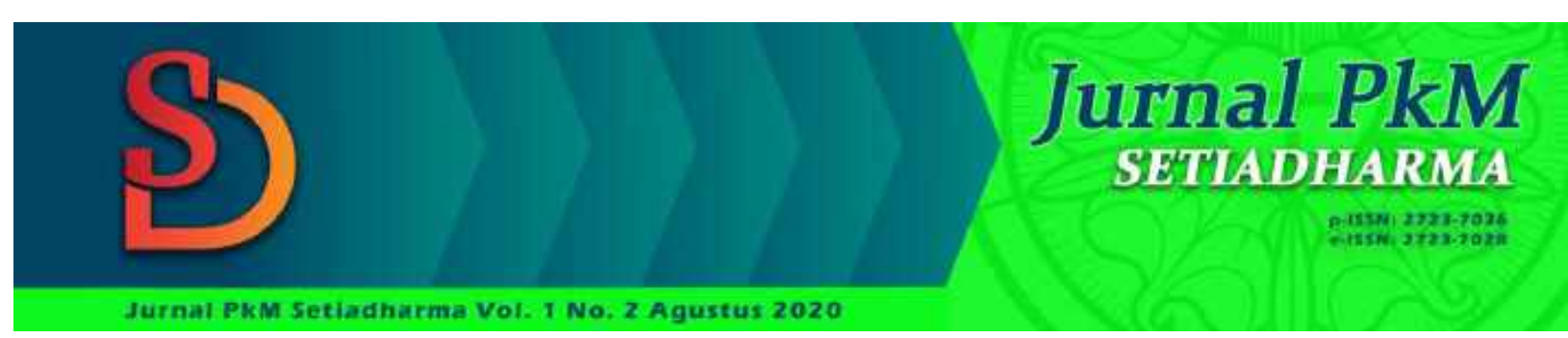

\title{
MISI KEMITRAAN MENGENTASKAN BUTA AKSARA DI DUSUN BAVUAYA DESA KARUVIA KECAMATAN PINEMBANI SULAWESI TENGAH DENGAN MEMBANGUN RUMAH BACA
}

\author{
Tony Salurante; ${ }^{1}$ Moses Wibowo ${ }^{2}$ \\ tony.salurante@sttsetia.ac.id \\ mwibowo@sttsetia.ac.id \\ Sekolah Tinggi Teologi Injili Arastamar (SETIA) Jakarta
}

Diterima:
01-09-2020
Direvisi:
16-09-2020
Diterbitkan:
30-09-2020
Kata Kunci:
Kemitraan Misi,
Misi Allah,
Rumah Baca,
Buta Aksara,
Bavuaya
Keywords:
Mission
Partnership, God
Mission,
Education House,
Illiterate
Bavuaya

\section{Abstrak}

Dusun Bavuaya merupakan salahsatu dusun di Desa Karuvia di Donggala Sulawesi Tengah. Keberadaan masyarakat yang masih tradisional membuat masyarakat menjadi wilayah yang tertinggal dalam berbagai hal. Selain masalah jarak yang jauh dari pusat desa karena hidup ditengah pegunungan. Masalah utama lain masyarakat di pegunungan Kecamatan Pinembani adalah masih buta huruf 99\%. Dalam rangka ikut serta program pemerintah dan terpanggil dalam menjalankan misi Allah, maka secara bersama menjalankan sebuah pendekatan untuk mengatasi masalah utama tersebut. Artikel ini menunjukkan bahwa sekalipun hamper 100\% buta aksara dan 80 tidak berbahasa Indonesia. Namun dengan melalukan Misi Kemitraan kendala utama tersebut dapat teratasi dan menunjukkan hasil positif. Selain hal tersebut program ini bertujuan juga untuk meningkatkan kualitas hidup masyarakat tertinggal secara sosial.

\section{Abstract}

Bavuaya is one of the rural-primitive areas in the Desa Karuvia in Donggala, Central Sulawesi. The tradisional community caused many backwardness in many matters. Another main problem is that the people in the mountains of Kecamatan Pinembani are still 99\% illiterate. This PkM-based article is part of the framework to actively participate in supporting the Indonesian government's program to eradicate illiteracy. This article shows that even though the challenges in rural missionary services are very difficult, by carrying out the Partnership Mission several major obstacles can be overcome and show positive results. This article shows that even though the challenges in rural missionary services are very difficult, several major obstacles can be overcome and deliver positive results by carrying out the Partnership Mission. This program also aims to improve the quality of life of socially disadvantaged people.

\footnotetext{
${ }^{1}$ Dosen Studi Interkultural di Sekolah Tinggi Teologi Injili Arastamar (SETIA) Jakarta

${ }^{2}$ Dosen Perjanjian Baru di Sekolah Tinggi Teologi Injili Arastamar (SETIA) Jakarta
} 


\section{PENDAHULUAN}

Di tengah kemajuan dunia dengan berbagai penemuan teknologi dan pesatnya pertumbuhan sekolah-sekolah swasta di seluruh Indonesia belum juga berhasil mengentaskan masalah bersama yaitu "buta huruf". Berbagai usaha dilakukan pemerintah untuk menuntaskan masalah pendidikan tersebut, sekitar $4 \%$ artinya ada sekitar 10 juta penduduk Indonesia yang tidak mengenal huruf. ${ }^{3}$ Berbagai program pemerintah untuk mendorong segenap lapisan masayarakt, pelaku pendidikan terlibat telah banyak membuahkan hasil, sekalipun perlu terus ditingkatkan.

Beberapa program pemerintah seperti dijelaskan oleh Direktur Jenderal Pendidikan Anak Usia Dini dan Pendidikan Masyarakat (PAUD Dikmas) Kementerian Pendidikan dan Kebudayaan (Kemendikbud) Harris Iskandar yang mengatakan bahwa sistem blok atau klaster, yaitu memusatkan program di daerah-daerah padat buta aksara. Program lain adalah pendidikan keaksaraan usaha mandiri (KUM) dan pendidikan multikeaksaraan. KUM berorientasi pada pemeliharaan keberaksaraan dengan fokus keterampilan usaha mandiri. Disamping tiga program tersebut Taman Bacaan Sekolah (TBS) juga menjadi hal yang digunakan untuk mempertahankan penduduk yang baru bisa membaca tadi. ${ }^{4}$ Program pemerintah tersebut masih perlu ditingkatkan di Indonesia terutama diwilayah-wilayah yang masih tertinggal, misalnya di daerah timur Indonesia seperti Sulawesi dan Papua.

Salah satu wilayah yang masih tertinggal dari masyarakat tradisional terdapat di kabupaten Donggala. Menentukan ciri-ciri apakah daerah tersebut tradisional dan terbelakang tidaklah sulit. Masyarakat tertinggal memiliki ciri-ciri mayoritas penduduk tidak memiliki Pendidikan formal, infrastruktur jalan yang masih sukar, dan Bahasa yang digunakan. Melihat 3 ciri yang tersebut maka dusun Bavuaya merupakan salah satu dusun yang memiliki ciri identik yang disebutkan itu. Ini merupakan ciri utama suatu wilayah yang terisolasi yang membuat pemerintah sulit menjangkauanya.

Wilayah terpencil yang sulit dijangkau menjadi alasan utama mengapa program pemerintah masih belum bisa terlaksana sepenuhnya dengan baik. Situasi ini mungkin sulit untuk diatasi jika hanya dilakukan sendiri tanpa ada campur tangan dari pihak lain. Wilayah ini adalah bagian paling kecil yang memotret betapa masih banyaknya tugas pemerintah yang perlu terus ditingkatkan. Tanpa ada kemitraan yang solid mustahil pelayanan misi yang mendukung program pemerintah dapat terlaksana dengan baik.

Secara definisi kolaborasi misi dalam pembahasan ini adalah kerja pelayanan gerejawi dalam bingkai mission dei yang terdiri dari berbagai organisasi. Sunquist menjelaskan dengan istilah lain yaitu misi kemitraan, ini merupakan sebuah konsep

\footnotetext{
${ }^{3}$ Danang Triatmojo, "Kemendikbud: 4 Persen Penduduk Indonesia Masih Buta Huruf," Tribunnews.Com. Diakses 27 Agustus 2020. https://www.tribunnews.com/nasional/2020/07/24/kemendikbud-4persen-penduduk-indonesia-masih-buta-huruf

${ }^{4}$ Inas Widyanuratikah, "Upaya Kemdikbud Mengatasi Buta Aksara Di Indonesia," Republika.Com. diakses 27 Agustus 2020. https://www.tribunnews.com/nasional/2020/07/24/kemendikbud-4-persen-pendudukindonesia-masih-buta-huruf.
} 
dinamis yang mengedepankan kesatuan sebagai tubuh Kristus. ${ }^{5}$ Misi Allah merupakan sumber misi gereja dimana setiap orang percaya menjadi alat-Nya untuk menyatakan kabar baik sekaligus menyebarkan kabar baik. Tidak hanya itu saja fokus misi gereja di dunia juga untuk menghadirkan nilai-nilai kebenaran Allah yang sejalan dengan program pemerintah. Pelayanan bersama yang dilakukan dalam masa waktu tertentu sampai tercapainya goal yang telah dilakukan secara bersama-sama. Orang percaya yang menjadi bagian dari Negara Kesatuan Republik Indonesia harus berperan aktif dalam berbagai skala. Mewujudkan Indonesia bebas buta aksara menjadi panggilan dalam pelayanan sosial. Merupakan peluang bagi gereja di Indonesia yang perlu dilakukan dan sebagaimana dalam artikel ini menunjukkan hasil yang positif.

Melihat berbagai latarbelakang masalah yang telah dipaparkan menegaskan bagaimana peran penting perguruan tinggi di Indonesia untuk menghasilkan lulusan untuk terlibat aktif dalam program-program pemerintah untuk mewujudkan peningkatan kualitas hidup masyarakat tertinggal di Indonesia. Seacara khusus Sekolah Tinggi Teologi yang memiliki misi pelayanan ke desa-desa memiliki peranan strategis untuk terlibat dalam program pemerintah yang sejalan dengan nilai-nilai kekristenan. Artikel ini menjawab pertanyaan bagaimana peranan dosen teologi ikut mewujudkan nilai-nilai kekristenan yang sejalan dengan program pemerintah dalam memberantas buta aksara di wilayah pedesaan? Artikel ini mengaskan bahwa perlu ditingkatkan kemitraan misi yang lebih luas lagi sehingga tugas yang berat ini dapat terlaksana secara lebih maksimal.

\section{METODE PELAKSANAAN}

Dalam kegiatan ini menggunakan metode pelayanan yang berkelanjutan (sustainable development). Bahwa apa yang dikerjakan pada tahap awal ini akan terus ditindaklanjuti dan ditingkatkan sehingga dapat mencapai hasil yang maksimal. Maka pada bebrapa tahap kegiatan perlu dilakukan. Adapun pelaksanaan kegiatan PkM meliputi proses yang cukup panjang. Adapun tahapan kegiatan PkM ini:

1. Survei, untuk menetapkan wilayah tertentu dalam program misi perlu pertimbangan yang panjang. Hal ini bertujuan untuk menghindari ekses negatif di wilayah yang baru dan tidak kita kenal sebelumnya. Pada tahap pertama ini secara bersamaan juga mempersiapkan strategi, tenaga dan dana untuk menjalankan program spesial ini. Diperlukan sikap mempertimbangkan sebanyak mungkin aspek sehingga diharapkan dapat mengurangi dampak negatif dan kesalahan-kesalahan dalam program ini.

2. Sosialisasi, bagian ini adalah salah satu tahap yang sulit dan membutuhkan waktu yang panajng. Dimana seorang utusan yaitu mahasiswa diutus untuk melakukan komunikasi serta mempelajari karakter sosial, budaya dan spiritualnya. Adanya keterbatasan komunikasi dalam bahasa dan jarak serta medan yang sukar untuk dijangkau maka perlu upaya ekstra untuk

${ }^{5}$ Scott W. Sunquist, Understanding Christian Mission: Participation in Suffering and Glory (Grand Rapids: Baker Academic, 2013), 379. 
mendapatkan titik temu bagaimana pelayanan dapat berlangsung sesuai dengan harapan.

3. Edukasi awal, setelah beberapa bulan mendoakan dan menjajaki berbagai latar belakang dan situasi maka tahap selanjutnya adalah edukasi tentang berbagai hal yang berelasi dengan peningkatan tarap hidup masyrakat pedesaan di dusun Bavuaya. Secara khusus adalah edukasi spiritual dan pendidikan yang menjadi konsentrasi awal pelayanan misi ini.

4. Perencanaan Pembangunan Rumah Baca, setelah terjalinnya dukungan dari berbagai pihak seperti gereja maka dimulailah perencanaan untuk membuat 1 gedung yang akan dijadikan pusat belajar masyrakat dalam hal ini anak-anak. Bagian terakhir merupakan awal dari tahap pendirian rumah baca, tahap berikutnya yaitu:

a. Presentasi ke Gereja pendukung tentang rencana pendirian bangunan rumah baca.

b. Pembuatan proposal anggaran dana

c. Penggalangan dana

d. Pengerjaan bangunan

e. Peresmian gedung

Kemitraan Misi (KM) bukanlah sebuah metode yang didalamnya terdapat susunan struktur dan aturan yang baku, KM merupakan mutualisme yang melihat kesejajaran antara setiap orang yang terlibat di dalamnya, penulis Ibrani berkata: "Marilah kita saling memperhatikan supaya kita saling mendorong dalam kasih dan dalam pekerjaan baik." (10:24). Prinsip pendekatan inilah yang digunakan dalam misi Pengabdian kepada Masyarakat di dusun terpencil di Bavuaya kabupaten Donggala Sulawesi Tengah. Adanya kesadaran akan keterbatasan di berbagai hal maka melalui metode KM akan mampu menyelesaikan masalah utama di masyarakat suku Kaili-Daa secara efektif.

\section{HASIL DAN PEMBAHASAN}

Tujuan dari Pengabdian kepada Masyarakat ${ }^{6}$ ini adalah mengentaskan buta huruf kepada seluruh anak-anak yang berjumlah kurang lebih 100 orang. Peran penulis dalam konteks ini mendorong terjadinya sebuah kolaborasi antara beberapa institusi dalam mencapai tujuan tersebut. Dimana sejauh ini buta huruf menjadi salah satu masalah yang belum mampu diatasi oleh pemerintah karena medan yang sulit dan keterbatasan tenaga pendidik. Bagi masyarakat di dusun Bavuaya Kecamatan Pinenbani pendidikan menjadi sebuah pengharapan yang dinantikan para orangtua sejak lama. Namun karena berbagai faktor, harapan tersebut tidak pernah terjadi. Pada tahun 2019 kami masuk di salah satu dusun yang masih termasuk dalam wilayah desa Karavia. Setelah melakukan survei maka 2 mahasiswa dari Sekolah Tinggi Teologia Star'Lub Luwuk Banggai diberangkatkan untuk memulai pelayanan selama 6 bulan. Selanjutnya diutus pendidik

\footnotetext{
${ }^{6}$ Selanjutnya akan disingkat menjadi PkM
} 
yang terdiri dari alumni dan mahasiswa Sekolah Tinggi Teologia Injili Arastamar (STT SETIA) Jakarta menjadi salah satu partner dalam menjalankan program ini.

Efektifitas misi gereja yang baik adalah menyadari bahwa pembaharuan hidup orang percaya juga ditopang salahsatunya melalui edukasi yang baik. Baik secara formal maupun non-formal. Sebagaimana menjadi visi dan misi STT SETIA Jakarta yaitu "to reach the unreached people". Slogan ini mendorong penulis untuk mengimplementasikan di daerah-daerah yang termarjinalkan. Namun misi ini tidak dapat memberi dampak yang besar jika dilakukan dengan sendiri saja. Menjalin kerjasama, mengajak terlibat dalam misi Allah merupakan tantangan dan kesempatan dalam zaman globalisasi saat ini. Situasi yang terus berubah dan berganti mempengaruhi juga cara bermisi gereja. Bukan saja pada pengertian dan pemahamannya, melainkan juga pada cara kerjanya. ${ }^{7}$

Dengan demikian situasi zaman sekarang merupakan kesempatan yang perlu diambil oleh banyak gereja dan sekolah-sekolah teologi untuk mendukung program pemerintah dalam bingkai panggilan kita sebagai orang percaya di konteks Indonesia. Masyarakat Bavuaya adalah masyarakat yang tertutup, tidak teredukasi serta memiliki pengetahuan sosial yang rendah. Kondisi ini menjadi tantangan dan juga peluang dalam mengimplematasikan ilmu dan juga iman bagi sesama warga negara Indonesia.

Rumah Baca tidak berbeda dengan Taman Baca atau Sekolah formal. Melalui memahami konteks yang ada maka Rumah Baca adalah yang paling memungkinkan untuk diimplementasikan. Rumah Baca didirikan ditengah perkampungan dengan luas 6x12 m terdiri dari 2 kelas. Kelas ini memiliki fasilitas berupa buku bacaan, meja dan kursi yang disesuaikan dengan kondisi di pegunungan. Sebelum Rumah Baca dibangun kegiatan edukasi dilakukan di pastori dan masih berlangsung sampai dengan saat ini. Hadirnya Rumah baca bisa mengedukasi beberapa hal diluar kegiatan membaca dan menulis, seperti misalnya kedisiplinan waktu, kebiasaan hidup sehat, dan sikap bertanggungjawab.

${ }^{7}$ David M. Sills, Changing World, Unchancing Mission: Responding to Global Challenges (Downers Grove: IVP Academic, 2015), 33-38. 


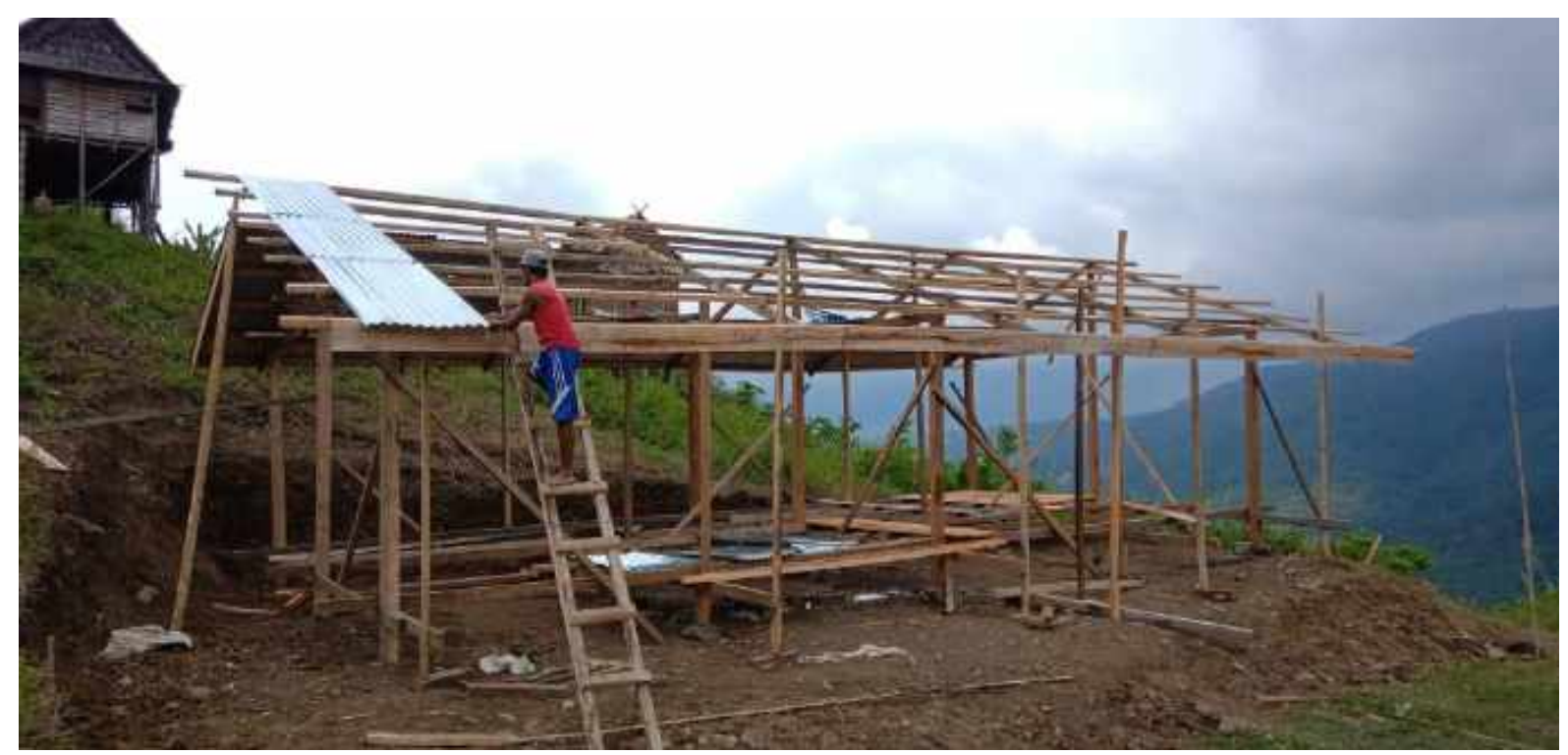

Gambar 1. Proses pembangunan Gedung Rumah Baca

Selain itu, rumah baca tidak hanya mendorong anak-anak untuk bisa membaca dan menulis saja. Namun perlu sebagai tempat dimana mereka belajar kehidupan sebagai suatu masyarakat. Kegiatan di Rumah Baca pastori guru-guru juga mengajar mereka bernyanyi. Anak-anak merupakan sasaran utama dalam misi ini. Melalui menjangkau anak-anak maka mereka juga dapat menjadi sarana yang efektif untuk mendidik orangtuanya dalam beberapa hal kecil. Seperti berbahasa Indonesia dan menyanyikan puji-pujian. Dampak ini cukup signifikan sebagai usaha membantu program mengentaskan buta huruf di kalangan orangtua.

\section{Jemaat Filipi Sebagai Dasar Membangun Misi Kemitraan}

Dalam Alkitab banyak contoh yang menunjukkan bagaimana misi para rasul didukung oleh orang-orang percaya lain sehingga para Rasul bisa fokus dalam memberitakan kabar baik (lih. 1 Kor. 16:6; Titus 3:13). Jemaat di Filipi merupakan contoh yang menjadi dasar kemitraan misi ini juga. Dalam surat Filipi menunjukkan jemaat yang memberi untuk mendukung pelayanan Paulus. Jemaat Filipi bermitra dengan Paulus menjadi sarana dalam pelayanan dan kemajuan Injili. ${ }^{8}$ Terutama pada pasal 4 dimana Paulus menjelaskan bahwa pemberian dari jemaat-jemaat tidak menunjukkan ordo dalam pelayanan dan menjadikan pemberian jemaat sebagai hal yang bukan terutama. Dalam hal ini pemberian jemaat dinilai sebagai hal yang sama bobotnya dengan pelayanan yang dilakukan Paulus (lih. ayat 14).

Keberadaan jemaat yang telah mendukung pelayanan sosial dalam memberantas buta huruf bukan pemberian persembahan belaka, namun bagian penting yang juga signifikan bagi kesatuan tubuh Kristus. Kesatuan dalam Kristus diwujudkan dalam persekutuan melakukan pekerjaan Tuhan di Bavuaya. Ada kesusahan yang masih mebelenggu masyarakat di sana karena terbelakang di banyak bidang, kedatangan guru,

${ }^{8}$ Dean Flemming, Recovering The Full Mission of God: A Biblical Perspective On Being, Doing and Telling (Downers Grove: IVP Academic, 2013), 191. 
hamba Tuhan menjadi solusi yang membebaskan mereka. Dengan terlibat dalam kemitraan misi berarti bersama merasakan penderitaan jemaat di Bavuaya. Sebagaimana Paulus jelaskan kepada jemaat di Filipi: "dalam pergumulan yang sama seperti yang dahulu kamu lihat padaku, dan yang sekarang kamu dengan tentang aku." (1:30). PkM ini bisa terlaksana karena dukungan banyak jemaat melalui beberapa gereja, baik yang berada di Jakarta maupun Sulawesi tengah sendiri dan juga pribadipribadi yang tidak mewakili organisasi apapun bahkan pemerintah setempat. Semuanya terlibat dan saling mendukung dengan memberikan apa yang terbaik, tidak ada yang paling berjasa karena semua satu.

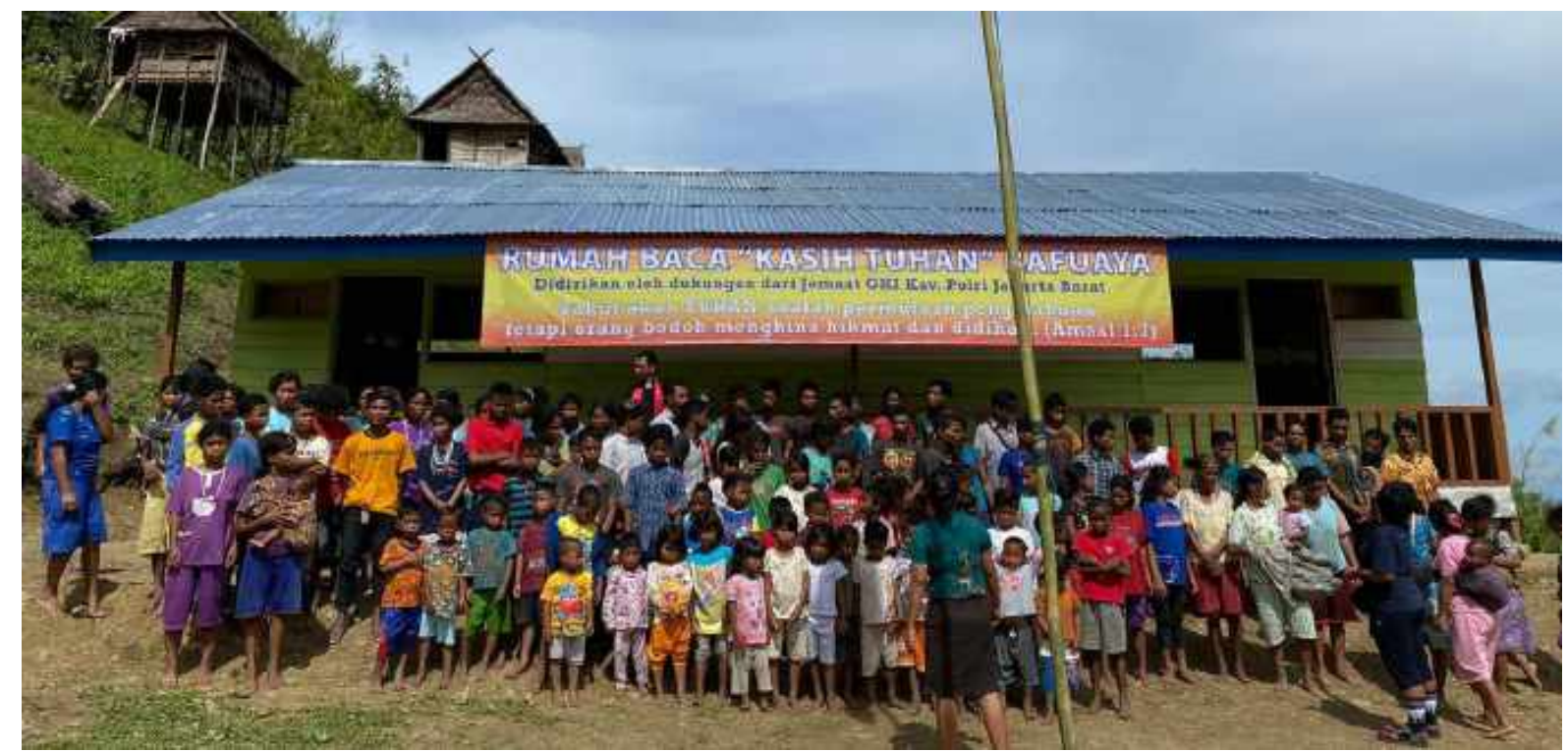

Gambar 2. Masyarakat Bavuaya di setelah Peresmian Gedung

\section{KESIMPULAN}

Kegiatan Pengabdian kepada Masyarakat di Bavuaya bukan sesuatu tindakan singkat yang dapat mengalahkan berbagai masalah. Dengan membuka rumah baca dan mengutus guru ditengah masyarakat yang didukung oleh berbagai pihak membuka kesempatan yang besar untuk melihat hasil dari pelayanan ini lebih berdampak lama. Tentu masih banyak hal yang perlu ditingkatkan, dipelihara sehingga menghasilkan buah yang manis. Hasil sementara menunjukkan hal positif dan signifikan yang perlu terus dipertahankan bahkan ditingkatkan. Saat ini kegiatan belajar masih berjalan nonformal karena situasi dan kondisi. Akan tetapi tidak mustahil jika dimasa yang akan datang status tersebut akan berubah menjadi sekolah formal.

Selain efektifitasnya dan fungsinya, kehadiran Rumah Baca ini akan mendorong terjadinya transformasi hidup. Indikasi ini terlihat dengan semakin terbukanya wawasan orangtua tentang kebenaran Firman Tuhan serta menghadirkan semangat anak-anak untuk belajar hal-hal baru. Semakin banyak ibu-ibu yang sudah menyadari bahwa anak-anak mereka harus belajar.

Tugas mulia ini tidak mungkin terjadi jika pemerintah tidak cakap dalam memetakan wilayah prioritas yang perlu menjadi perhatian. Laporan pemerintah di tingkat desa perlu terkoneksi dengan pemerintah pusat sehingga dapat mengatasi prosedur dukungan yang terkesan lambat bahkan tertinggal. Membuka diri untuk memberi dukungan penuh kepada sekolah-sekolah yang memiliki kesamaan misi dengan pemerintah. Pelayanan misi ini hanya satu dari banyak pekerjaan yang haru 
smenjadi perhatian kita bersama. Sehingga nilai-nilai kekristenan dan nilai luhur Pancasila dapat terwujud bagi wilayah-wilayah yang belum terjangkau seperti dusun Bavuaya ini.
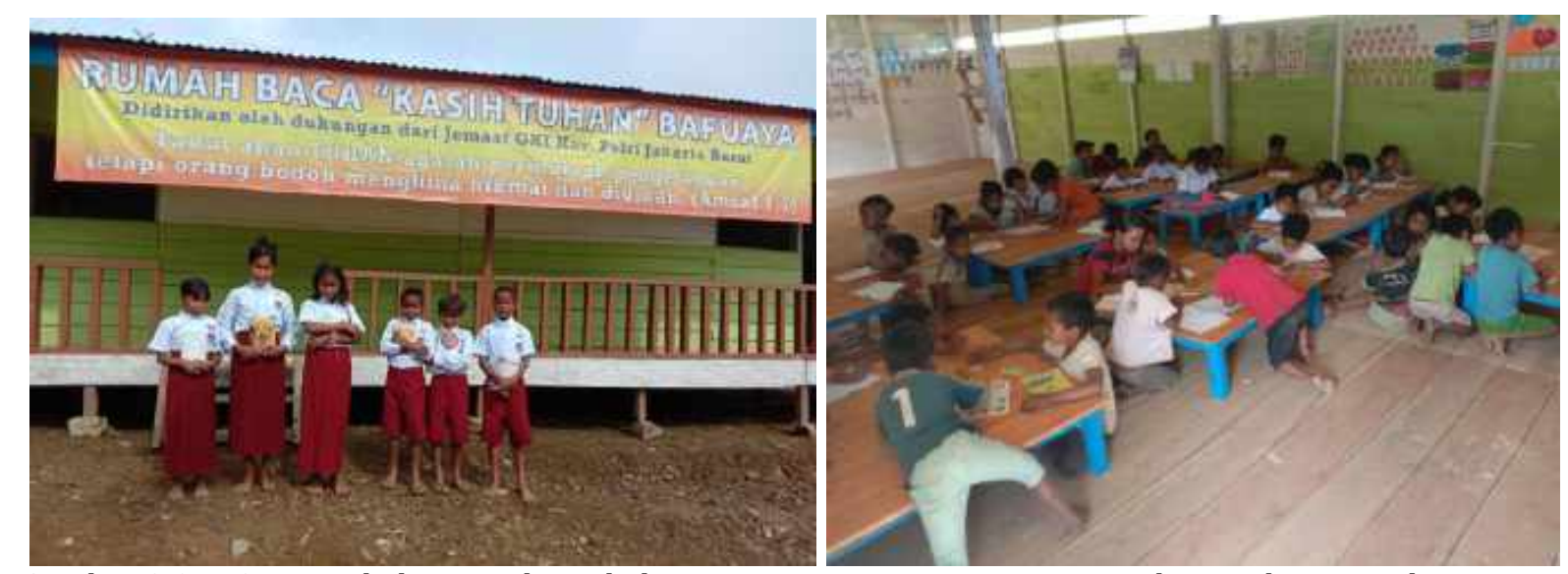

Gambar 3 \& 4. Suasana belajar anak-anak di Bavuaya Desa Karuvia, Kec. Pinenbani Kab. Donggala

\section{DAFTAR PUSTAKA}

\section{Website:}

Triatmojo, Danang. "Kemendikbud: 4 Persen Penduduk Indonesia Masih Buta Huruf." Tribunnews.Com.

Widyanuratikah, Inas. "Upaya Kemdikbud Mengatasi Buta Aksara Di Indonesia." Republika.Com.

\section{Literatur}

Flemming, Dean. Recovering The Full Mission of God: A Biblical Perspective On Being, Doing and Telling. Downers Grove: IVP Academic, 2013.

Sills, David M. Changing World, Unchancing Mission: Responding to Global Challenges. Downers Grove: IVP Academic, 2015.

Sunquist, Scott W. Understanding Christian Mission: Participation in Suffering and Glory. Grand Rapids: Baker Academic, 2013. 